\title{
実験河川石礫床区間への土砂供給による 河床状態と流水抵抗の変化に関する実験的研究 STUDY ON CHANGES IN BED CONDITION AND FLOW RESISTANCE OF GRAVEL BED CAUSED BY SAND SUPPLY IN THE EXPERIMENTAL RIVER
}

\author{
原田守啓 1 ・藤田裕一郎 2 - 水上精栄 3 ・萱場祐一 4 \\ Morihiro HARADA, Yuichiro FUJITA, Seiei MIZUKAMI, Yuichi KAYABA \\ 1正会員 工修 大日コンサルタント株式会社 環境・水工部（テ500-8384 岐阜市薮田南3-1-21） \\ 2フェロー 工博 岐阜大学流域圈科学研究センター教授（†501-1193 岐阜市柳戸1番1） \\ 3正会員 工修 岐阜大学工学部 技術専門員（干501-1193 岐阜市柳戸1番1） \\ 4正会員 工博 （独）土木研究所自然共生研究センター（テ501-6021 各務原市川島笠田町無番地）
}

\begin{abstract}
Changes in bed condition, flow resistance and sediment transport are discussed in gravel-cobble covered bed where sand is supplied artificially like as river reaches downstream of dam reservoirs, on the basis of experimental results obtained in a large scale flume called "the experimental river" in the Aqua Restoration Research Center, PWRI. Variations of the bed condition were clarified minutely by the use of a sophisticated system that enables automatic measurement of $1 \mathrm{~cm}$ mesh intervals even under flowing conditions. Flow resistance and non-equilibrium process of sediment transport are confirmed to correspond closely to bed states under subcritical condition.
\end{abstract}

Key Words: sediment supply, gravel riverbed, flow resistance, field observation method

\section{1. はじめに}

山地から河口，海域に至る土砂生産・土砂移動のシ ステムを流砂系と捉え，その健全化に向けた「総合土砂 管理」の概念1)が提示されて，既に10年余りが経過して いる. その間に，流砂系スケールでの土砂移動の実態把 握の調査やその技術開発と平行して，砂防堰堤や貯水ダ ムを対象とした「土砂を流寸」施策が展開されてきた. 特に，貯水ダムの土砂管理及び堆砂対策は，堆砂により 低下した貯水容量を回復し，ダムの長寿命化を図る観点 から重要であり, 各種の堆砂対策 ${ }^{2}$ の事例数の増加に よって，知見の蓄積が進みつつある.

ダム堆砂対策のうち, サンドバイパス等の恒久対策 施設の事例はまだ少なく, 貯水池で浚渫した土砂をダム 下流に還元する手法が日本各地の相当数のダムで試験的 に実施されている. 貯水池での浚渫自体は, 従来から維 持管理の一環として行われてきたものであり，この手法 は，特別な施設を要しない土砂還元手法として注目され， 平成20年には土木学会水理委員会環境水理部会主催で

「置き土シンポジウム」が開催されるまでとなった.

置き土が流水によって浸食を受ける過程については, 従来の流路変動研究の延長上にあることから, 現地観測 や模型実験, 数值解析等の事例队4等が報告されており, 置き土の浸食過程や下流河川に流出寸る土砂の量につい ては，ある程度定量的な予測が可能となりつつある。
また, ダム下流の物理環境と生物・生態系との関係 に関する既往の知見の蓄積) は，土砂還元に対する下流 河川の応答について, 定性的な予測を可能としている.

しかしながら，還元した土砂が下流河川をどのよう に流下し，どのような場所に留まるのか，という基本的 な点については未解明な点が多いと考えられる.

その要因の一つとして, 現地において還元した土砂 を追跡することが物理的に困難であることが挙げられる. 例えば，置き土による土砂還元の先駆的事例である，天 竜川の発電ダム群の事例のでは, 還元量が河川規模に対 して限定的な状況では，下流河床における変化を把握す ることは困難であることが指摘されている.

また, ダムの立地条件から, 土砂が還元される区間 は主に山地部であるから，還元された土砂の移動を予測 するには, 粒径オーダーが異なる河床材料で構成される 河床における流砂量を表現しうるモデルが必要となる. とくに, 河川環境に対しては, 大径の石碩が動かない程 度の流況下での土砂の挙動の取り扱いが重要と考えられ, 芦田・藤田ら ${ }^{7,8}$ によよって提示された, 碩による遮蔽効 果や砂の存在割合を考慮した浮遊砂量算定式などが現象 の分析に適用されている. 藤田ら ${ }^{9}$ は, 石礫床に細砂を 供給する実験を $1 / 100$ 勾配に設定した大規模水路で行い, 礫間の堆積状況と浮遊砂量との関係を調べて, 土砂供給 量の増加に伴い砂面高が上昇するという基本的な挙動を 確認するとともに，それが流水抵抗特性に大きな変化を 
もたらさなかったことを報告し，目視結果と限界流に近 い水理条件から，流送土砂量について既往の浮遊砂量算 定式を適用して，計測值との差異について考察している。 本研究は，同様に，動かない石砂の間を砂が掃流状 に流下寸る状況に対象を絞り，河床表層や土砂流送の状 態について，11より実河川に近い条件で定量的に観測を 行うこと, (2)水理量・流砂量の変化に対寸る河床面の応 答を流水を遮断しないで連続的にとらえることを目的に， (独) 土木研究所自然共生研究センターの実験河川におい て，石碩河床区間に連続的に給砂する実験を行い，土砂 の挙動とともに，それに密接な関係を有する河床の流水 抵抗特性について検討と考察を加えたものである.

\section{2. 実験方法と実験条件}

\section{（1）実験河川における給砂実験の概要}

実験は，(独）士木研究所自然共生研究センター内の実 験河川(岐阜県各務原市)の一部を利用して行った．実験 河川は，一級河川木曽川北派川に人工的に流路を造成し たものであり，木曽川支川新境川（流域面積 $42.6 \mathrm{~km}^{2}$ ， 流路延長 $13.6 \mathrm{~km}$ ） から流路上流の調節池に河川水を導水 し，流量制御のための鋼製起伏ゲートを介して，河川水 を自然流下させるもので，延長約 $800 \mathrm{~m}$ ，河幅約 $2 \sim 6 \mathrm{~m}$ ， 河床勾配は1/200〜800である.

本実験は，3本ある実験河川のうちB河川の上流側に， 本実験のために新設した給砂区間（約60m） と，粒径 $100 \mathrm{~mm}$ 程度のほぼ一様な鿬を敷き詰めた河床幅 $2 \mathrm{~m}$ ，河

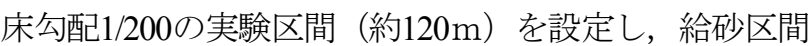
に盛った土砂を実験区間に自然流下させる形で，土砂供 給を行った。給砂区間は，区間下流端に固定堰（高さ

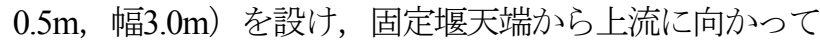
一定の縦断勾配で土砂を盛る構造とした．給砂区間及び 実験区間の状況を図-1に示す。

給砂に用いた土砂は，調達可能な土砂の量，実河川に 流入する実験河川の特性等を考慮して，木曾川産の川砂 とした．粒度試験の結果を表-1に示寸。

なお，この実験系は，数週間に亘って水と土砂を定常 的に流し続けられるよう設計されたものであり，本実験 は，実験河川における給砂実験時の河床の基本的な応答， 給砂区間からの土砂の流出特性を把握する目的も兼ねて 実施した。

\section{(2) 測定項目及び測定方法 \\ a) 河床高の平面分布}

流量及び流砂量に対する河床表層の状態，具体的には， 礫間の空隙が流下土砂により閉塞している状態を，水が 流れている状況下で詳細に計測するため，河床高を面的 に計測する装置を構築して，実験区間上流端から $20 \mathrm{~m} の$ 地点に設定して定点観測した

装置は，約 $4 \mathrm{~m} \times 2 \mathrm{~m}$ のアルミフレーム製枠に，分解能 $50 \mu \mathrm{m}$ のレーザー変位計(KEYENCE製)を取り付けたX,Y
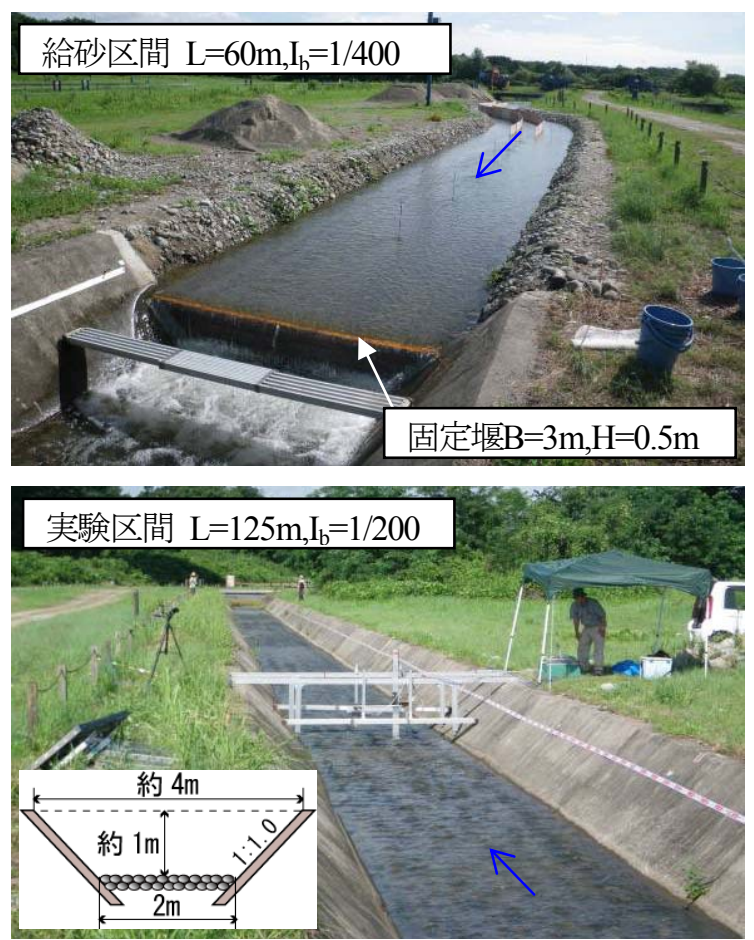

図-1＼cjkstart給砂区間，実験区間の状況

表-1 給砂した土砂の粒度分布諸元

\begin{tabular}{|l|r|}
\hline 土粒子密度 $\rho_{s}\left[\mathrm{~g} / \mathrm{cm}^{3}\right]$ & 2.64 \\
\hline 礫分 $(2 \sim 75 \mathrm{~mm})[\%]$ & 21.20 \\
\hline 砂分 $(0.075 \sim 2 \mathrm{~mm})[\%]$ & 69.40 \\
\hline シルト分 $(0.005 \sim 0.075 \mathrm{~mm})[\%]$ & 5.70 \\
\hline 粘土分 $(0.005 \mathrm{~mm}$ 末満 $)[\%]$ & 3.70 \\
\hline 最大粒径 $[\mathrm{mm}]$ & 9.50 \\
\hline 中央粒径 $\mathrm{D}_{50}[\mathrm{~mm}]$ & 0.4875 \\
\hline 均等係数 $U_{c}$ & 8.16 \\
\hline
\end{tabular}

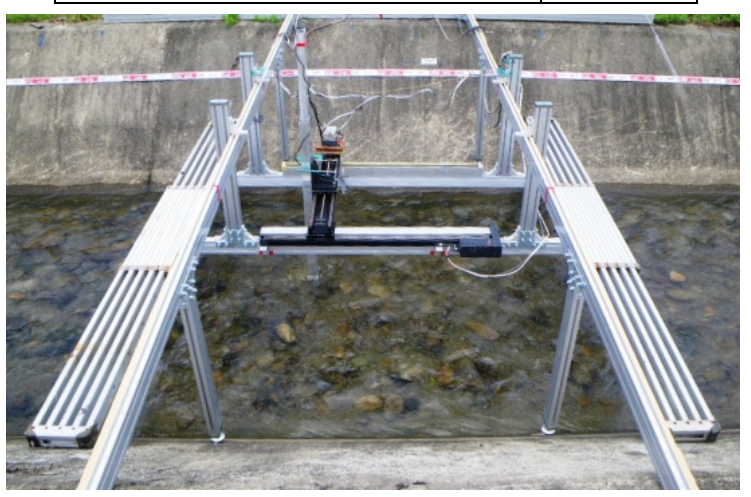

写真-1＼cjkstart河床高計測装置の外観

2軸のアクチュエータ(THK製)を上載した架台を吊り下 げた構造とし，1回の自動計測で，流下方向 $1 \mathrm{~m} \times$ 横断方 向 $0.5 \mathrm{~m}$ の範囲にある $1 \mathrm{~cm}$ メシュの河床高を計測可能と

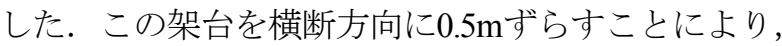
$1 \mathrm{~m} \times 1 \mathrm{~m}(100 \times 100$ 点 $)$ の河床高を計測した．装置の外観 を写真-1に示寸.

レーザー変位計は，水面による乱反射を防ぐため，先 端に透明アクリル板を固定した鞘状の部材の内部に収め, 流量が最も少ない実験ケースの際に，先端のアクリル板 が水面よりわずかに水没するようにセットした．各計測 
点において, レーザー変位計が出力する電圧值をPCに 取り込み，あらかじめ作成しておいた検定式で，河床高 に変換した. 河床高平面分布の経時的な変化を可能な限 り短い間隔て観測するため, アクチュエータの制御プロ グラムを調整し，自動計測 1 回 $(1 \mathrm{~m} \times 0.5 \mathrm{~m})$ あたり 6 分 程度で計測した。

b) 水位

河床高の計測を1セット行う毎に，河床高の計測範囲 $1 \mathrm{~m} \times 1 \mathrm{~m}$ の上下流計6点の水位を, 護岸天端から水面まで の比高差として鋼尺で計測した。また，維断方向 $10 \mathrm{~m}$ お きの水位を定期的に計測し, 水位縦断図に整理した.

\section{c）実験区間への給砂量}

実験区間への給砂量は，給砂区間下流端の固定堰にお いて，本実験に合わせて製作したサーバーネット

（HOGA社製，開口部 $500 \mathrm{~mm} \times 100 \mathrm{~mm}$ ，目合 $(0.5 \mathrm{~mm})$ により，堰を越流する流砂を捕捉して計測した．計測は， 河床高計測の前後に行った.

採取した土砂を, 湿潤した状態のままメスシリンダー に入れ，清水を一定の体積まで満たして重量を計測し， 清水のみでの計測値との差分から, 砂の量を算出した.

固定堰を越流する流砂量は，流量の設定によっては， 給砂区間に河床波が発生することによって, 時間的・空 間的に周期的に変化するため, 河床波の移動速度の観測 を踏まえ，一回あたりの計測時間を調整した．捕捉した 試料は持ち帰り, 粒度試験を行った。

河床高平面分布の計測箇所の直下流においても，河床 にサーバーネットを固定して流砂量の計測を試みたが， 河床面に密着して固定することが困難であったことから， 流砂量については採用せず，流砂の粒度分布を確認する ための参考試料とした.

\section{（3）実験ケース}

実験条件は流量と給砂区間の縦断勾配によってコント ロールするものとし，予備実験を踏まえ，給砂区間の縦 断勾配は $1 / 400$, 流量は $100 \mathrm{~L} / \mathrm{s}, 150 \mathrm{~L} / \mathrm{s}, 200 \mathrm{~L} / \mathrm{s}$ のケース とした. 実験河川は, より大きい流量の放流が可能であ るが，予備実験の結果，流量の増加に伴って給砂区間に 河床波が発達して流砂量が頭打ちになりはじめる200L/s を上限とし, 給砂区間において移動限界程度となる 100L/sを下限とした. 実験条件を表-2に示寸。

実験は平成22年7月17日〜20日の4日間で行い，あらか じめ $100 \mathrm{~L} / \mathrm{s}$ で通水し, 流量を $150 \mathrm{~L} / \mathrm{s}, 200 \mathrm{~L} / \mathrm{s}$ と変化させて, 各流量で河床が十分落ち着いたと判断される状態に達し た状況と, 流量を変化させた直後から河床が変化してい く状況をそれぞれ複数回計測した.

なお，給砂量は実験区間上流端にあたる固定堰で複数 回計測した平均值, 水深は河床表層の変化に対応した変 動が見られたため，実験区間における複数回計測の平均 值を示す.
表-2 実験条件一覧

\begin{tabular}{|c|c|c|c|c|c|}
\hline 流量 & $\begin{array}{c}\text { 単位幅 } \\
\text { 流量 }\end{array}$ & $\begin{array}{c}\text { 給砂量 } \\
\text { (平均值) }\end{array}$ & $\begin{array}{c}\text { 単位幅 } \\
\text { 給砂量 }\end{array}$ & $\begin{array}{c}\text { 水深 } \\
\text { (平均值) }\end{array}$ & $\begin{array}{c}\text { 通水 } \\
\text { 時間 }\end{array}$ \\
\hline $\mathrm{L} / \mathrm{s}$ & $\mathrm{m}^{3} / \mathrm{s} / \mathrm{m}$ & \multicolumn{1}{c}{$\mathrm{cm}^{3} / \mathrm{s}$} & $\mathrm{cm}^{3} / \mathrm{s} / \mathrm{m}$ & $\mathrm{cm}$ & $\mathrm{hr}$ \\
\hline 100 & 0.050 & 0.988 & 0.494 & 9.1 & 23 \\
\hline 150 & 0.075 & 2.067 & 1.034 & 11.7 & 20 \\
\hline 200 & 0.100 & 2.634 & 1.317 & 14.4 & 4 \\
\hline
\end{tabular}

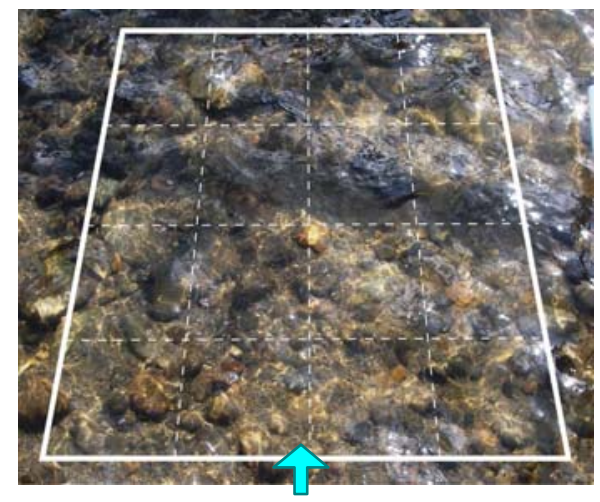

写真-2 河床高計測範囲の状況 $(Q=100 \mathrm{~L} / \mathrm{s})$
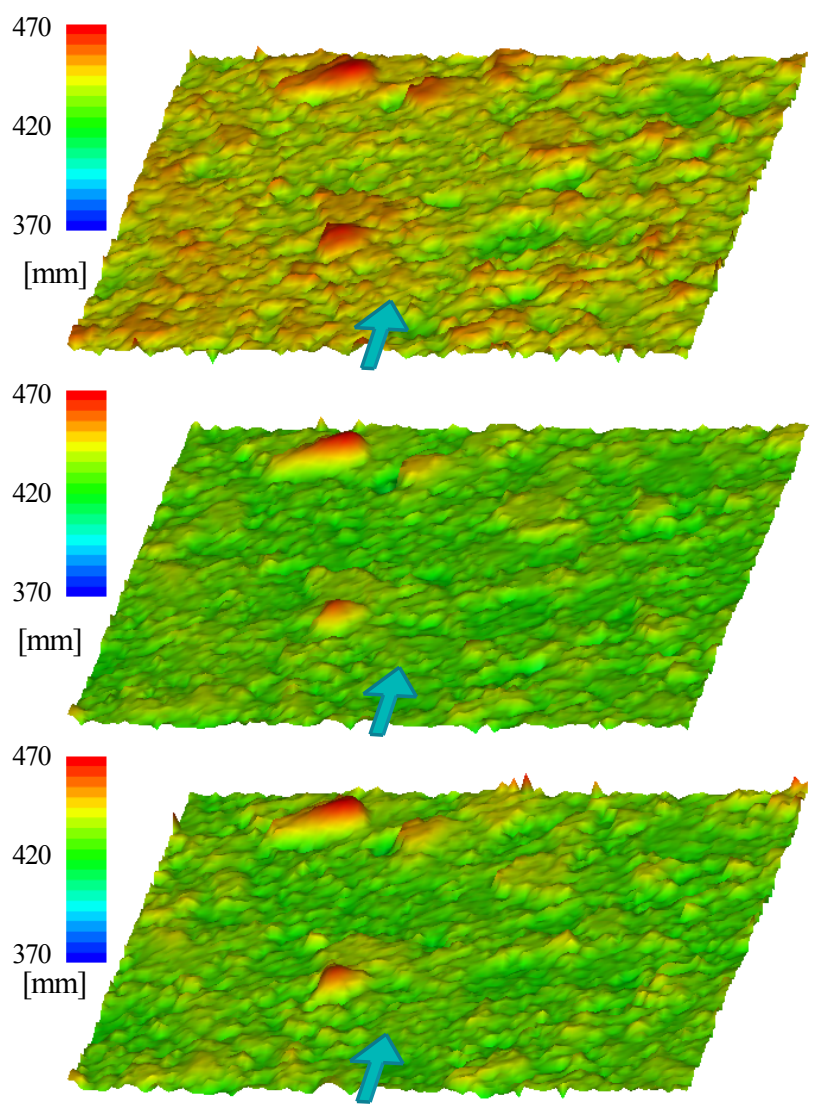

図-2 河床高測定結果の例

（上から $Q=100 \mathrm{~L} / \mathrm{s}, 150 \mathrm{~L} / \mathrm{s}, 200 \mathrm{~L} / \mathrm{s}$ の最終状態）

\section{3. 実験結果及び考察}

\section{(1) 河床高計測結果}

計測範囲 $(1 \mathrm{~m} \times 1 \mathrm{~m})$ の状況を写真 $-2 に$, 河床高計測結 果の例を図-2に示す．なお，河床高の基準は水路両岸の 護岸天端高から-1.5mの高さとし，上方向を正とした.

測定結果は, 砂面から突出している石䋸の形状, 肉眼 
では把握できない砂面の凹凸を詳細に捉えることができ ており, 河床上の細砂量の変化を, 河床高の差分から検 討することを可能としている。 しかしながら，上面から の河床観測手法の特性として，石礫の裏側やレーザー反 射光が遮蔽される石碩の影部の空隙状況については把握 することはできていない，また，レーザー変位計を納め た角パイプの先端を水面下に十分挿入できなかった条件 下には，その下に空気が入り込んで，測定值が取得でき ない場合があった。

\section{(2) 流量と流砂量の変化に対する河床の応答の観測}

鿬床に土砂を供給すると，定性的には，䂢間の寉みが 砂で埋塞されることによって, 石碩床の形状抵抗が減少 し, 流速は増加, 水深は低下寸ると考えられる. 水深の 低下は，全掃流力の減少につながるが，砂粒への有效掃 流力はさほど下がらないと考えられるので, 河床表面に 占める砂粒の割合が増加すれば，それだけ流砂量も増加 し，上流からの供給土砂量に見合った動的平衡に至るも のと考えられる.

本実験の経過に伴って, 各流量段階について $1 \mathrm{~m} \times 1 \mathrm{~m}$ で測定された水位および河床高の変化を図-3に示寸.

流量を増加させた直後から, 最低河床高及び平均河床 高が一度上昇し, その後下がって, 動的平衡に向かう変 化が確認された. この理由は次のように考察される. 流 量の増加に伴って, 局所的な流砂量の不均衡, 寸なわち, $100 \mathrm{~L} / \mathrm{s}$ に対して平衡状態にあると判断される最終時点の 高い砂粒被覆率の河床に $150 \mathrm{~L} / \mathrm{s}$ の流量が供給されたこと でpick-up rateが上昇し，その累積結果が反映される計測 位置では, 上流からの流砂量が一時的に増加して, 河床 が上昇したと考えられる.

ついで，上流区間から順次，供給される流量と土砂量 に釣り合った河床状態が下流に向けて伝搬していくと考 えられ，その釣り合った $150 \mathrm{~L} / \mathrm{s} の$ 平衡状態の砂面被覆率 が100L/sの場合よりも低いために，河床は低下したと判 断される. 流量が150L/sから200L/sに増加した場合には, 上述の状況がより明確な形で繰り返されており, 後述の 河床変動量の変化を見ると流量が大きい分, 平衡状態に より早く到達しているようである.
肉眼での観察では砂面の被覆状態の変化はほぼ追えた ものの, 砂面高さの一時的な上昇を明確に確認すること は困難であったことを考慮すると，水を流しながら，河 床高を面的に計測可能であるという本計測法のメリット が最大限発揮された観測結果であるといえる.

\section{(3) 河床が流水に及ぼす抵抗の算定}

流量を100L/sから150L/sに，また，150L/sから200L/sに 変化させた直後には, ともに, 流量増に対応した水位の 上昇が観測されたが，その後，平均河床の上昇に追随し て上昇したのち, 平均河床が低下しているにもかかわら ず水位は上昇している.

このときの水理量の変化を表-3に, 流速係数 $\phi$ の変化 を図-4に示す．なお水理量の整理では，簡単のため，流 れは等流状態と仮定して, エネルギー勾配は河床勾配に 等しい1/200としている.

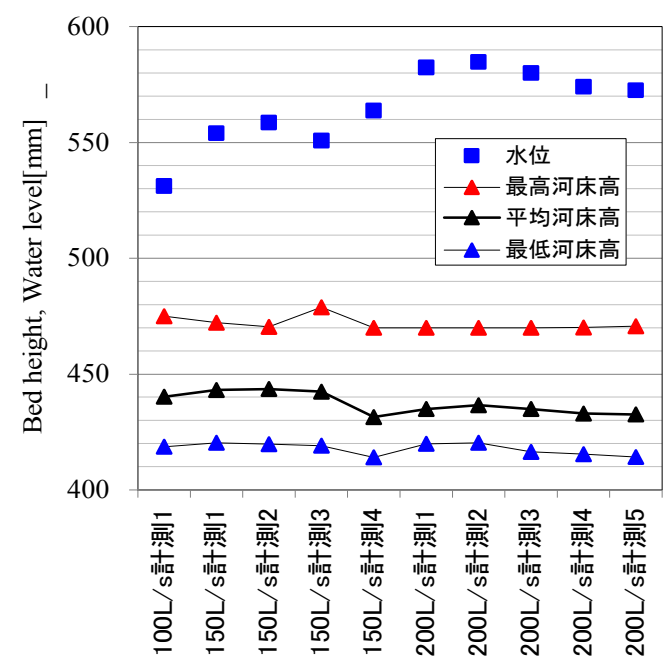

図-3 計測ケース毎の河床高・水位

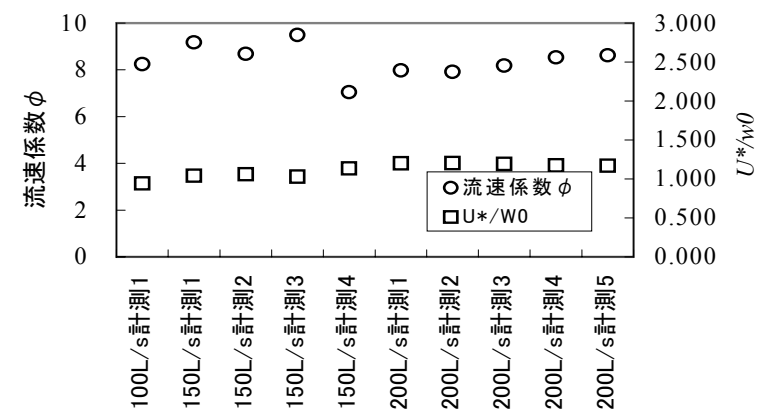

図-4 流速係数 $\phi, \mathrm{U} * / \mathrm{w} 0$

表-3 測定ケース毎の水理量一覧

\begin{tabular}{|c|c|c|c|c|c|c|c|c|c|c|c|c|c|}
\hline \multirow[t]{2}{*}{ No. } & \multirow{2}{*}{ ケース名 } & 流量 & 水位 & \multicolumn{3}{|c|}{ 河床高Z } & \multirow{2}{*}{$\begin{array}{c}\text { 平均水深 } \\
\mathrm{H}[\mathrm{mm}]\end{array}$} & \multirow{2}{*}{ 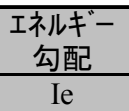 } & \multirow{2}{*}{$\begin{array}{l}\text { 平均流速 } \\
\mathrm{U}[\mathrm{cm} / \mathrm{s}]\end{array}$} & \multirow{2}{*}{$\frac{\text { 摩擦速度 }}{\mathrm{U}^{*}[\mathrm{~cm} / \mathrm{s}]}$} & \multirow{2}{*}{ 流速係数 } & \multirow{2}{*}{ 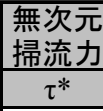 } & \multirow[t]{2}{*}{$\mathrm{U}^{*} / \mathrm{W} 0$} \\
\hline & & $\mathrm{Q}[\mathrm{L} / \mathrm{s}]$ & $\mathrm{WL}[\mathrm{mm}]$ & 平均 & 最高 & 最低 & & & & & & & \\
\hline 1 & 100L/s計測1 & 100 & 531 & 440 & 475 & 419 & 91 & 0.005 & 55.0 & 6.7 & 8.24 & 0.46 & 0.9 \\
\hline 2 & $150 \mathrm{~L} / \mathrm{s}$ & 150 & 554 & 443 & 472 & 420 & 111 & 0.005 & 67.6 & $\overline{7.4}$ & 9.17 & 0.56 & 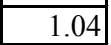 \\
\hline & $150 \mathrm{~L}$ & 150 & 559 & 443 & 470 & 420 & 115 & 0.005 & 65.2 & 7.5 & 8.69 & 0.58 & 1.0 \\
\hline 4 & $150 \mathrm{~L}$ & 150 & 551 & 442 & 479 & 419 & 108 & 0.005 & 69.2 & 7.3 & 9.50 & 0.55 & 1.0 \\
\hline 5 & $150 \mathrm{~L}$ & 1 & 5 & 4 & 470 & 414 & 132 & 0.00 & 56.7 & 8.1 & 7.04 & 0.67 & 1.1 \\
\hline 6 & $200 \mathrm{~L}$ & 200 & 582 & 435 & 470 & 420 & 147 & 0.00 & 67.8 & 8.5 & 7.98 & 0.75 & 1.2 \\
\hline 7 & $200 \mathrm{~L} / \mathrm{s}$ & 200 & 585 & 437 & 470 & 420 & 148 & 0.005 & 67.5 & 8.5 & 7.92 & 0.75 & 1.2 \\
\hline 8 & $200 \mathrm{~L} / \mathrm{s}$ & 200 & 580 & 435 & 470 & 416 & 145 & 0.005 & 68.9 & 8.4 & 8.18 & 0.74 & 1.1 \\
\hline 9 & $200 \mathrm{~L} / \mathrm{s}$ & 200 & 574 & 433 & 470 & 415 & 141 & 0.005 & 70.9 & 8.3 & 8.53 & 0.72 & 1.1 \\
\hline 10 & $200 \mathrm{~L} / \mathrm{s}$ 計測 5 & 200 & 573 & 432 & 471 & 414 & 140 & 0.005 & 71.4 & 8.3 & 8.62 & 0.71 & 1.17 \\
\hline
\end{tabular}


本実験では, 藤田ら99の実験結果とは異なり, 流量を 増加させた直後のように，碩間を埋めて砂面高が上昇す ると, 流速係数 $\phi$ の值が上昇している. また, 河床高に 相対的な差のある, $150 \mathrm{~L} / \mathrm{s} の$ 計測1〜3と200L/sの計測1〜 5 とを比較すると, 明らかに平均的に河床高の低い後者 の流速係数值が小さくなっている．このような結果の相 違は，既に指摘したように，常流下で実施された本実験 とは異なり, 藤田らの実験が限界流に近い条件であって, 流砂形態も浮流となっていたために，石磼の形状抵抗に 大きな差が現れなかったことが考えられる.

\section{（4）既往の流砂量算定式の適用性の検討}

観測結果から整理した平均的な水理量を用いて, 既往 の流砂量式を適用した際に, 観測した現象をどの程度説 明しうるか，簡易な検討を行った．また，流砂量の算定 は，河床高計測区間の下流で捕捉した流砂試料の粒度試 験の結果より，代表粒径を0.6mmとして算出した．流砂 量式は, $U^{*} / w_{0}$ が最大でも 1.2 程度であり, この摩擦速 度には石砂の形状抵抗が含まれていることと, 観察に基 づき，全量を掃流砂として算出することとした.

流砂量は, 以下の4通りの方法で算出した。

一つ目は，(1)式に示寸芦田・道上式10)であり，全掃流 力により流砂量を求めた結果を，表-4(2欄に示す.

$$
q_{B^{*}}=17 \tau_{*}^{3 / 2}\left(1-\frac{\tau_{*_{c}}}{\tau_{*}}\right)\left(1-\sqrt{\frac{\tau_{*_{c}}}{\tau_{*}}}\right)
$$

算出された值は，石碩の形状抵抗も含む全掃流力が砂 粒で覆われた平坦河床に作用した場合の平衡流砂量であ るから, 当然過大な值となり, 給砂量に対して2オー ダーほど大きい，ここでは，表面積に占める移動可能な 砂の割合を考慮していないが，值を砂被覆率等によって 補正したとしても過大である.

次に, 全掃流力から, 移動しない石碩の形状抵抗分離 を，(2)式に示寸芦田・道上の有効掃流力 ${ }^{10)}$ によって試 み, その結果を表-4(3)闌に示寸.この式は砂堆河床等を 対象として河床波背面で対数抵抗則が成立するとして導 かれたものではあるが，ここでは，石礫を乗り越したり その側方を通過する砂粒について，同様の考えが成り立 つと仮定して適用したものである.

$$
\frac{U}{U_{*_{e}}}=6.0+5.75 \log _{10} \frac{H}{D\left(1+2 \tau_{*}\right)}
$$

また，通常，混合粒径砂碩の移動限界には，遮蔽効果 が考慮されるが，本実験のように粒径が数オーダー異な る 2 群の材料で河床が構成される場合, 既往の評価式で 参照される平均粒径の物理的意味が希薄となり, やはり, 砂粒の被覆率と遮蔽効果との関係を明確にすることが本 質問題となるが，これについては今後の課題としたい．

(2)式を適用した流砂量は，給砂量の10倍程度であり， 表面積に占める移動可能な砂の割合を考慮すれば，本実 験に関しては計算值が給砂量に近い值となり，興味深い，

次に, 表層の不均質に起因して生じる非平衡状態を評 価するため，その不均質性を流砂量に明示的に反映しう

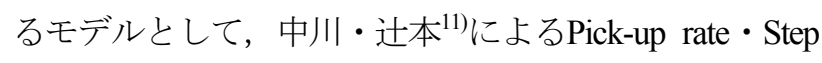
length型の流砂量評価法を用いる.

無次元Pick-up rateを(3)式, 無次元Step lengthを(4)式, 単位面積に存在する移動可能な砂の体積を $V_{b}$ として, 流 砂量は(5)式に表される.

$$
\begin{aligned}
& P_{s}^{*} \equiv P_{s} \sqrt{D /(R g)}=0.03 \times \tau_{*}\left(1-\frac{0.035}{\tau_{*}}\right)^{3} \\
& \lambda \equiv \Lambda / D=3.0 \times 10^{3} \times\left(\frac{u_{*}}{w_{0}}\right)^{3 / 2}\left(1-\frac{u_{*_{c}}}{u_{*}}\right) \\
& q_{B}=V_{b} \times P_{s} \times \Lambda
\end{aligned}
$$

本実験条件を(4)式に適用し, step lengthを算出したと ころ, 粒径の $2,000 〜 3,000$ 倍と算出されたが，本式の導 出過程で用いられたデータは， $\tau_{*}$ が 0.3 程度までの実験 結果であって, step lengthの実測值は粒子径の200〜300 倍程度で頭打ちとなる傾向が知られている. 一方, 流砂 量式との比較ではそこから漸増していくように予測され ている. そこで, 仮に $\lambda=200$ と置き, 流砂量を求めた 結果を表-4(4)欄に示す. その結果は, やはり過大評価と なった。また，(2)式による有効掃流力を(3)式に適用し た結果は, 有効掃流力を用いた芦田・道上式とほぼ同様 の值（表-4(5)欄）となった.

\section{(5) 河床高の変化からみた流砂量の変動}

実験中に観測した砂面高の上昇・下降を，流砂量と関 係づけて検討するため, 連続する2ケースの河床高測定 結果の差分から, 土砂体積の変化量 $\Delta V$ を求め, 単位時

\begin{tabular}{|c|c|c|c|c|c|c|c|c|c|c|c|c|c|c|c|}
\hline \multirow{3}{*}{ No. } & \multirow{3}{*}{ ケース名 } & $\begin{array}{l}\text { (1)単位幅 } \\
\text { 給砂量 }\end{array}$ & $\begin{array}{l}\text { (2)芦田·道上式 } \\
\text { (全掃流力) }\end{array}$ & \multicolumn{3}{|c|}{$\begin{array}{l}\text { (3)芦田·道上式 } \\
\text { (有効掃流力) }\end{array}$} & \multicolumn{4}{|c|}{$\begin{array}{l}\text { (4)中川·辻本式 } \\
\text { (全掃流力) }\end{array}$} & \multicolumn{2}{|c|}{$\begin{array}{c}\text { (5)中川-辻本式 } \\
\text { (有効掃流力) } \\
\end{array}$} & \multicolumn{3}{|c|}{ 6河床変動量からの逆算 } \\
\hline & & $\mathrm{qB}$ & $\mathrm{qB}$ & $\mathrm{U} * \mathrm{e}$ & $\tau * \mathrm{e}$ & $\mathrm{qB}$ & Ps* & $\lambda$ & $\mathrm{Vb}$ & $q B$ & Ps* & $\mathrm{qB}$ & $\Delta \mathrm{V}$ & $\Delta T$ & $\Delta q B$ \\
\hline & & {$\left[\mathrm{cm}^{3} / \mathrm{s} / \mathrm{m}\right]$} & {$\left[\mathrm{cm}^{3} / \mathrm{s} / \mathrm{m}\right]$} & {$[\mathrm{cm} / \mathrm{s}]$} & - & {$\left[\mathrm{cm}^{3} / \mathrm{s} / \mathrm{m}\right]$} & - & - & {$\left[\mathrm{cm}^{3}\right]$} & {$\left[\mathrm{cm}^{3} / \mathrm{s} / \mathrm{m}\right]$} & - & {$\left[\mathrm{cm}^{3} / \mathrm{s} / \mathrm{m}\right]$} & {$\left[\mathrm{cm}^{3} / \mathrm{m}^{2}\right]$} & [min] & {$\left[\mathrm{cm}^{3} / \mathrm{s} / \mathrm{m}\right]$} \\
\hline 1 & $100 \mathrm{~L} / \mathrm{s}$ 平衡 & 0.494 & 124.1 & 3.25 & 0.11 & \begin{tabular}{|r|}
6.4 \\
\end{tabular} & 0.0109 & 200 & 0.031 & \begin{tabular}{|r|}
67.5 \\
\end{tabular} & 0.0010 & \begin{tabular}{|r|}
6.4 \\
\end{tabular} & - & - & - \\
\hline 2 & $150 \mathrm{~L} / \mathrm{s}$ 非平衡 1 & 1.034 & 175.8 & 3.94 & 0.16 & 16.0 & 0.0139 & 200 & 0.031 & 86.0 & 0.0023 & 14.3 & 2852 & 105 & 0.453 \\
\hline 3 & 150L/s非平衡2 & 1.034 & 187.2 & 3.79 & 0.15 & 13.4 & 0.0146 & 200 & 0.031 & 89.8 & 0.0020 & 12.4 & 374 & 35 & 0.178 \\
\hline 4 & 150L/s非平衡3 & 1.034 & 168.9 & 4.04 & 0.17 & 17.8 & 0.0136 & 200 & 0.031 & 83.7 & 0.0025 & 15.6 & -1028 & 43 & -0.399 \\
\hline 5 & 150L/s平衡 & 1.034 & 238.0 & 3.27 & 0.11 & 6.5 & 0.0172 & 200 & 0.031 & 105.9 & 0.0011 & 6.6 & -11087 & 995 & -0.186 \\
\hline 6 & 200L/s非平衡1 & 1.317 & 286.1 & 3.88 & 0.16 & 14.9 & 0.0195 & 200 & 0.031 & 120.1 & 0.0022 & 13.5 & 3497 & 30 & 1.943 \\
\hline 7 & 200L/s非平衡2 & 1.317 & 288.3 & 3.87 & 0.15 & 14.6 & 0.0196 & 200 & 0.031 & 120.7 & 0.0022 & 13.3 & 1659 & 34 & 0.813 \\
\hline 8 & $200 \mathrm{~L} / \mathrm{s}$ 非平衡3 & 1.317 & 278.3 & 3.95 & 0.16 & 16.1 & 0.0191 & 200 & 0.031 & 117.9 & 0.0023 & 14.4 & -1594 & 36 & -0.738 \\
\hline 9 & 200L/s非平衡4 & 1.317 & 265.2 & 4.07 & 0.17 & 18.4 & 0.0185 & 200 & 0.031 & 114.1 & 0.0026 & 16.1 & -1940 & 80 & -0.404 \\
\hline 10 & $200 \mathrm{~L} / \mathrm{s}$ 平衡 & 1.317 & 262.0 & 4.10 & 0.17 & 19.0 & 0.0183 & 200 & 0.031 & 113.1 & 0.0027 & 16.5 & -495 & 115 & -0.079 \\
\hline
\end{tabular}
間あたりの土砂収支を算出することを試みた.

土砂体積の変化量 $\Delta V$ は, 計測範囲に流入寸る流砂 量と流出する流砂量との差の時間積分值に等しいとし,

表-4 実験区間への供砂量, 既往の流砂量式の適用結果及び河床変化量の比較 
(6)式を定義して, 簡単のため空隙率入を 0.4 と仮定して, 単位時間あたりの流砂量の差分 $\Delta q_{B}$ を算出した. 結果を 表-4(6)欄に示寸.

$\Delta V=\int_{t}^{t+\Delta t}\left(\frac{q_{\text {Bin }}-q_{\text {Bout }}}{\Delta x}\right) d t \cdot \frac{\Delta x}{1-\lambda} B=\Delta t \cdot \Delta q_{B} \cdot \frac{1}{1-\lambda} B$

算出した $\Delta q_{B}$ の絶対值は，実験区間に供給される流砂 量に対して，0.6〜1.5倍程度であり，流量が変化した直 後や, 同一流量を流し続ける中での, 砂粒の平均的な堆 積過程や離脱過程のゆらぎによって生じる流砂量の変動 が平均流砂量程度であることを定量的に捉えていると考 えられる。

\section{4. 結論と課題}

本研究は, (独) 土木研究所の自然共生研究センターの 実験河川において，石碩河床に砂を供給した際の河床表 層の変化を，流水を遮断しないてて観測する手法を試行し， 観測結果に基づいて, 磎間の土砂の挙動とともに，それ に密接な関係を有寸る河床の流水抵抗特性について検討 と考察を加えたものである. 以下に主な結論を示す.

(1)レーザー変位計 2 次元とアクチュエータを用いた計測 装置により, 河床高の平面分布を, 流水を遮断せず, 精度良く計測することができた.

(2)石㗂の空隙に砂が堆積もしくは流出することにより， 河床の流水抵抗が変化することを確認した.

(3)移動しない石鿬床を細粒の掃流砂が移動する状況につ いて，既存の掃流砂量式を適用した結果，全掃流力を 用いた場合，極端な過大評価となることを確認した。

(4)河床波のある場合を対象とした有效掃流力評価を既存 の流砂量式に試行的に適用した結果, 本実験について は現象にかなり近い流砂量が算出された.

(5)河床高の平面分布の時間差分より, 同一流量を流し続 ける中で生じている, 砂粒の平均的な堆積過程や離脱 過程のゆらぎに伴う流砂量の変動の状態が平均流砂量 と同程度であることを定量的に捉えることができた。

以上のように，本実験で用いたレーザー変位計による 河床高の平面分布の計測では, 水を流したまま河床高の 微細な変化を, 比較的短い時間で繰り返し計測すること により, 計測対象範囲の路床変動を定量的に把握するこ とができたが，小水深の場合には水面から空気が回り込 んだり，砂床面に影響を与える可能性もあったので，形 状を改良するとともに適用限界を明らかにして石㗂周辺 の砂の挙動のより仔細な把握を進め, その機構の考察に 生かしていくつもりである

また，本計測方法の根本的な課題である以下の点につ いても検討していきたい.

流砂量が非常に多い場合, 浮遊砂濃度が高い場合は,
レーザー計測は困難であると考えられるが，得られた信 号が何を示しているかは検討の価值があるであろう.

さらに，上面からの観測手法では，当然石碩の裏側や レーザー反射光が遮蔽される石䋹の影部の空隙状況につ いては把握できない，この点に関しては, 碩の形状を幾 何学モデル化し, 観測可能な上面から裏面の状況を推定 する方法等が考えられる.

また, 本計測手法の発展として, 河床高の平面分布を 計測すると同時に，計測した点が，砂面か石礫の表面で あるのか，判別できることが望ましい，河床表層の状況 を判別する手法を開発もしくは別手法として本手法に組 み合わせることによって, 石磼と砂が混在する河床表層 における流水抵抗と流砂のメカニズムの解明に資する計 測手法となりうるものと考えている.

謝辞 : 猛暑の中, 野外での実験に粘り強く取り組んでい ただいた, 岐阜大学河川工学研究室の学生諸氏に, 深い 感謝の意を表します。

\section{参考文献}

1) 河川審議会 総合政策委員会 総合土砂管理小委員会：「流 砂系の総合的な土砂管理に向けて」報告, pp.1-12, 1998.

2) ダム水源地環境整備センター研究第1部 : ダムの堆砂対策技 術ノート:ダム機能向上と環境改善に向けて, pp.33-55, 2008.

3) 重枝未玲, 秋山壽一郎, 小牧貴大, 高須賀真哉: 河道への 置き砂還元プロセスの平面 2 次元数值シミュレーション, 水 工学論文集, 第50巻, pp.1015-1020, 2006.

4) 佐々木崇憲, 櫻井寿之, 箱石憲昭: 三春ダム直下流におけ 万置土侵食の平面 2 次元河床変動解析, 土木学会第63回年次 学術講演会講演概要集 II, pp.253-254, 2008.

5) ダムと下流河川の物理環境との関係についての捉え方-下流 河川の生物・生態系との関係把握に向けて- : 国土技術政策 総合研究書資料No.521/土木研究所資料N No.4140, 2009.

6) 岡野眞久, 菊井幹男, 石田裕哉, 角 哲也 : ダム貯水池堆砂 とそのダム下流河川還元についての研究，河川技術論文集， 第10巻, pp.191-196, 2004.

7) 芦田和男, 藤田正治 : 河床粒子の浮遊機構とそのモデル化, 土木学会論文集, 第375号/II-6, pp.79-88, 1986.

8) 芦田和男, 藤田正治 : 平衡および非平衡流砂量算定の確率 モデル，土木学会論文集，第375号/II-6, pp.107-116， 1986.

9) 藤田光一 - 山原康嗣 - 冨田陽子 - 伊藤嘉奈子 - 小路剛志 : 大磎床表面における砂の堆積状況と浮遊砂量との関係につい ての実験的研究, 水工学論文集, 第52巻, pp.547-552, 2008.

10) 土木学会 : 水理公式集平成11年版, pp.162-166, 1999.

11) 中川博次, 辻本哲郎: 新体系土木工学 23 移動床流れの水理, 技報堂出版，pp.49-98，1986.

(2010. 9. 30受付) 